Int. J. Dev. Biol. 50: 665-674 (2006)

doi: $10.1387 / \mathrm{ijdb} .062159 \mathrm{mg}$

Review

\title{
Retinal ganglion cells: dying to survive
}

\author{
MARC B. GUERIN1, DECLAN P. McKERNAN', COLM J. O'BRIEN² and THOMAS G. COTTER ${ }^{1, *}$ \\ ${ }^{1}$ Cell Development \& Disease Laboratory, Department of Biochemistry, Biosciences Institute, University College Cork, Cork and \\ ${ }^{2}$ Institute of Ophthalmology, Mater Misericordiae Hospital and Conway Institute, University College Dublin, Dublin, Ireland
}

\section{CONTENTS}

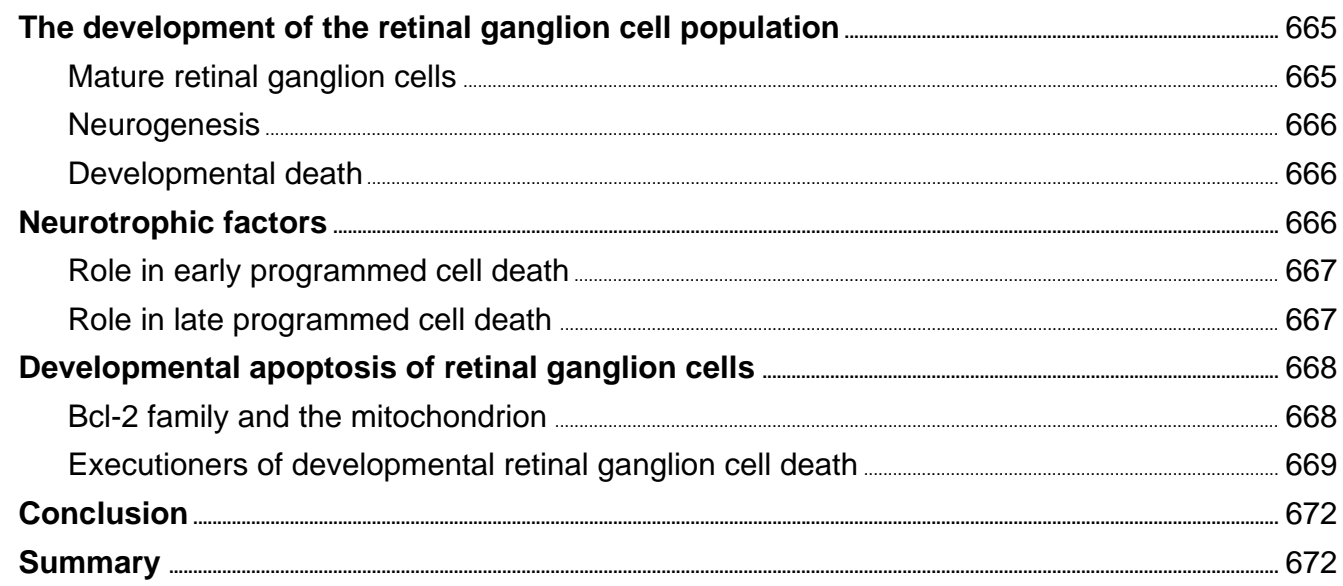

\section{Introduction}

Developmental tissue homeostasis relies on the exquisite balance between cell death and proliferation. Central to such maturation in the central nervous systems is apoptosis. This unique form of programmed cell death (PCD) is implicated not only in several pathologies of the mature retina, but also maintains a fundamental role in the sculpture of this organ at both the embryonic and post-natal stages. The vertebrate retina develops from a single layer of undifferentiated neuroepithelial cells into a multilayered structure of terminally differentiated neurons. These retinal neurons, including the retinal ganglion cell (RGC) population, produced in excess during neurogenesis, are then partially eliminated by a series of apoptotic waves, before finally achieving a mature, post developmental state.

\section{The development of the retinal ganglion cell population}

\section{Mature retinal ganglion cells}

Adult RGCs are a heterogeneous, finite population of post mitotic neurons in the retina of the vertebrate eye (Fig. 1). Though mainly located within the innermost nucleated layer of the mature retina, the somata of some RGCs are displaced from this ganglion cell layer (GCL) to the inner plexiform layer (Buhl and Dann, 1988) (Fig. 2). Conversely, up to $50 \%$ of the cells within the GCL of the rat may be amacrine cells (Bunt and Lund, 1974, Perry, 1981).

As the only output neurons of the retina, RGCs possess the unique ability to process and project information from the retina to visual centres such as the superior collicullis (SC), pretectal nuclei and the lateral geniculate nucleus (Fig. 3). These retinal projections manage to precisely map the distinct topography of the retina to the visual centres. Over $90 \%$ of rat RGCs project to the contralateral SC, with $30 \%$ sending collaterals to the lateral geniculate nucleus in the thalamus (Dreher et al., 1985). Sensory information is conveyed along the unmyelinated RGC axons to the optic nerve head, whereupon the converging axons become

Abbreviations used in this paper: $\mathrm{AIF}$, apoptosis inducing factor; $\mathrm{BDNF}$, brain derived growth factor; $\mathrm{BH}$, bcl-2 homology domain; cAMP, adenosine 3', 5' - cyclic monophosphate; CNS, central nervous system; E, embroyonic day; FADD, fas activated death domain; GCL, ganglion cell layer; IAP, inhibitor of apoptosis proteins; MEF, mouse embryonic fibroblasts; MMP, mitochondrial membrane permeabilization; NGF, nerve growth factor; NTF, neurotrophin3; ON, optic nerve; P, postnatal day; PCD, programmed cell death; RGC, retinal ganglion cell; Shh, sonic hedgehog; TRK, tyrosine kinase; TUNEL, Tdt-mediated dUTP Nick End Labelling. 
encased in oligodendrocyte derived myelin sheaths to form the optic nerve (ON). Counting ON axons in a transverse section has provided accurate estimates of retinal ganglion cell numbers in various species. Approximating only $1 \%$ of total cells within the mouse retina, RGC totals have varied from 32,000 to 87,000 among diverse strains of this species (Williams et al., 1996). RGCs in the adult rat have been estimated to total approximately 96,200-118,300 (Forrester and Peters, 1967, Danias et al., 2002).

\section{Neurogenesis}

RGC development may be divided into overlapping stages of specification, migration and differentiation. Originating from multipotent heterogeneous progenitor cells, RGCs are the first retinal neurons to be produced during vertebral retinogenesis (Young et al., 1985a). These neurons originate between embryonic day 13 (E13) and E19 in the rat, E11 to postnatal day 0 (P0) in the mouse and between E2 and E6 in the chick (Dallimore et al., 2002, Isenmann etal., 2003, Prada etal., 1991). It is believed that the decision of a pluripotent progenitor retinal cell to specifically become an RGC is taken postmitotically (Mu and Klein, 2004). The intrinsic gene expression within such a progenitor cell is suggested to be central to this crucial decision to evolve into a particular cell type (Cepko et al., 1996). Genes such as pax 6,

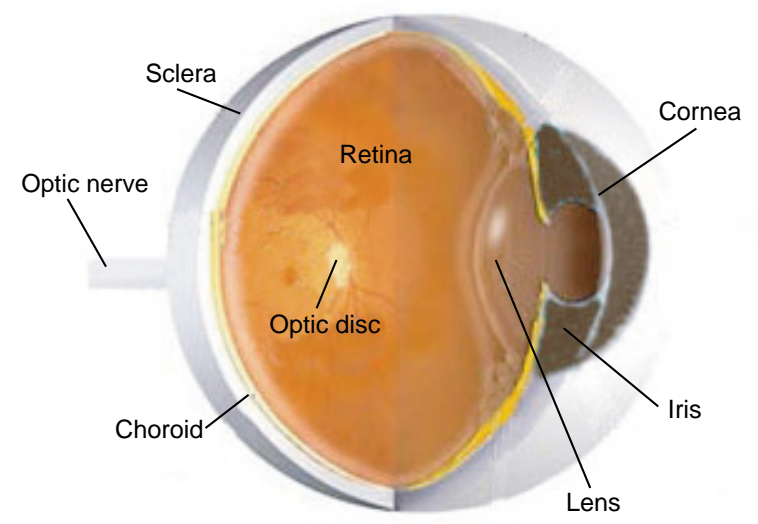

Fig. 1. Anatomy of the vertebrate eye. The retina, lining the inner aspect of the eye, extends posteriorly to the optic nerve. Axons from the retinal ganglion cells converge at the optic disc, where they fuse to become the optic nerve. This nerve emerges from the posterior ocular surface and exits the orbit through the optic foramen.

math 5, sonic hedgehog (shh) and notch play a regulatory role in RGC specification. In particular, math 5 plays a significant positive role in mouse RGC development and activity of this gene in retinal precursor cells appears to promote RGC specification (Brown et al., 2001, Wang et al., 2001). Shh is one of the earliest factors promoting a RGC phenotype and also appears to regulate expression of pax 6 . This latter gene plays a central role in eye development, as illustrated by a mouse conditional knockout of pax 6 which results in inhibition of RGC specification during development, allowing only amacrine cells to specify in the retina (Marquardt et al., 2001). In contrast, notch maintains a negative influence on RGC production (Austin et al., 1995).

Once specified, newly postmitotic RGCs migrate to the marginal zone of the primitive retina to form the inner neuroblastic layer (NBL). While in the process of migration, RGCs may commence terminal differentiation under the influence of genes such as brn3b(Gan etal., 1999). RGCs extend their axons into the $\mathrm{ON}$ before commencement of dendritic formation (Maslim et al., 1986). Amacrine cells are then the first neighbouring cells to which RGCs seek to extend dendritic arbors, closely followed by connections to bipolar and horizontal neurons (Sernagor et al., 2001). Dendritic arbors then complete their development in a centroperipheral direction (Sernagor et al., 2001). The retinal axons of the first born RGCs initially innervate the superior colliculus in the rat at E16/16.5, whilst the connection of later born cells can occur up to P4 or P5 (Lund and Bunt 1976, Dallimore et al., 2002). Dallimore et al. also report that axons from the earliest born RGCs reach the fetal superior colliculus within 3 days of their birth, whereas axons born from E19 RGCs can take up to 8-9 days to reach their central targets (Dallimore et al., 2002). Another study reports that $R G C s$ generated by $E 16$ have connected to the superior colliculus by birth, whilst RGCs emerging around birth take until P5 (Isenmann et al., 2003).

\section{Developmental death}

First to be born in species such as the rat, RGCs are also the first neurons within the retina to die. There exists two distinct periods of developmental cell death, comprising an early phase coinciding with the onset of neuronal birth, differentiation and migration (E5 to E7 in chick and E15-E17 in the mouse) and a later phase involving physiological cell death which coincides with target innervation (Frade et al., 1997, Perry and Cowey, 1982, Perry et al., 1983). This second phase of death may simply be a "fine tuning" of cell death, ensuring that only target innervated cells survive (Galli-Resta and Ensini, 1996).

RGC degeneration in the mouse is evident up to P11, but peaks between P2-P5 (Young et al., 1984). Counts of ON axons have estimated that $50 \%$ of newly generated rats RGCs die within the first week, soon after reaching their target superior colliculus and lateral geniculate nucleus (Perry et al., 1993). This, however, may be a significant underestimation of the total number of RGCs eliminated, as migration of newly generated RGCs to their layer takes place over several days and many undergo apoptosis prior to complete migration of the entire population. By analysing the elimination of RGCs with distinct embryonic birth dates, it has been approximated that up to one million RGCs undergo developmental cell death, thus up to $90 \%$ of RGCs have undergone PCD during RGC development (Galli-Resta and Ensini 1996). This report also noted the existence of a temporal relationship between neurogenesis and death of individual neurons. This "cell death clock" indicates that developmental death of rat RGCs occurs within 5 days of their genesis, independent of their time of birth. It also contends that newly generated cells take at least three days to migrate to the GCL and remain there no longer than 2 days before they die. However these findings have been contradicted in the mouse retina, where it was noted that cells in the GCL were actually spared in the immediate aftermath of their birth (Farah and Easter, 2005).

\section{Neurotrophic factors}

Expressed both in the retina and the primary visual centres, neurotrophic factors can regulate survival, differentiation and regeneration of neurons through their autocrine, endocrine and 
paracrine properties (Herzog and von Bartheld, 1998). In an effort to survive during development, RGCs actually compete for these polypeptide factors supplied by target structures such as the superior colliculus. If an RGC axonal projection fails to accurately innervate its intended target, it is eliminated due to deprivation of trophic factors necessary for survival. However, it also appears that neurotrophic factors may be derived locally from surrounding cells (Herzog and von Barthold 1998). Indeed, RGCs themselves may synthesise neurotrophic factors and it has been demonstrated that rat RGCs may be influenced by local intraretinal neurotrophic release (von Bartheld et al., 1996, Spalding et al., 2005, Wang et al., 2002). Neurotrophic factors implicated in developmental apoptosis include the neurotrophin family comprising 6 related factors; Brain Derived Neurotrophic Factors (BDNF), Nerve Growth Factor (NGF), Neurotrophin-3, Neurotrophin-4/5, NeuroTrophin-6 and NeuroTrophin7. These trophins may bind to two families of transmembrane receptors, including the TRK receptors within the tyrosine kinase family for which they have a strong affinity and the extracellular domain of the p75 neurotrophin receptor (Kaplan and Miller, 2000). These families of receptors may then directly interact with each other, allowing for further crosstalk between these pathways (Bibel and Barde, 2000).

\section{Role in early programmed cell death}

Early PCD appears to be strongly influenced by neurotrophins such as NGF and BDNF, amongst others. RGCs not only exhibit BDNF receptors (Garner et al., 1996) but also possess BDNF protein and RNA at E4 (Frade and Barde, 1999). It has been further documented that the exogenous application of BDNF to chick embryos in ovo reduces early PCD of RGCs at E6 and increases the axonal population at E9 (Frade et al., 1997, Frade et al., 1996). It was noted that BDNF did not actually increase RGC production at E6 per se, but did increase the number of cells arriving at the vitreal surface, thus appearing to rescue migrating RGCs from death. Furthermore, they observed that the GCL cell population was increased by $90 \%$ at E9, with a $60 \%$ increase in optic nerve axon number. However, this reduction in RGC death subsequent to BDNF application may simply be a temporary stay on execution, as it has shown that BDNF null mice have normal numbers of RGCs at birth (Cellerino and Kohler, 1997).

Contrary to the documented pro survival effects of NGF in other neuronal developmental paradigms, accurate axonal innervation may trigger NGF to stimulate early RGC death. Citing the opposing capabilities of this neurotrophin within differing systems, it has been suggested that neurotrophins might perhaps be more appropriately termed "neuromodulators" (Yuan and Yanker, 2000). NGF can directly activate RGC death by binding to p75 and activating a complex intracellular pathway involving ceramide production (Frade and Barde, 1997, Carter and Lewin, 1997). Further evidence indicating NGF involvement includes the use of anti NGF and anti-p75NTR antibodies to inhibit RGC death at E6 in the chick retina (Frade and Barde, 1999, Frade et al., 1996). Furthermore, early PCD is inhibited in $\mathrm{NGF}^{-/-}$mice and in p75NTR- (ii)

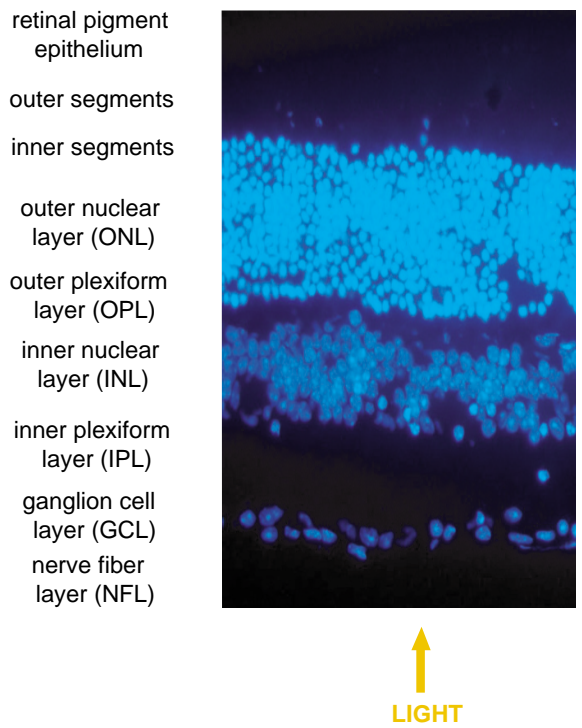

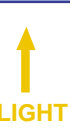

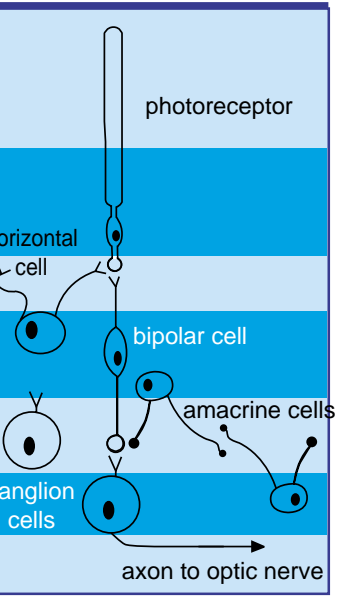

. rat adult rat retina contain cell bodies, including the ganglion cell layer (GCL), which the innermost nucleated layer of the retina. Though mostly containing retinal anglion cells (RGCS), up to $50 \%$ of the cells within the rat GCL may be amacrine cells. xiform layer. RGCs form synaptic connections with neighbouring bipolar and macrine cells. Axonal projections from RGCs, constituting the Nerve Fibre Layer (NFL), travel to the optic disc where they converge to form the optic nerve.
1- mouse embryos (Frade et al., 1996, Frade and Barde, 1999). NT3 may also have a role in RCG protection during development. Anti-NT3 antibodies have been shown to reduce RGC population significantly by $\mathrm{E} 6$ in the chick retina and only $35 \%$ are present at E16 (Bovolenta et al., 1996).

\section{Role in late programmed cell death}

The role of BDNF at the latter stage of PCD remains contentious. Early embroyonic RGCs can survive without BDNF but they become dependent on BDNF in vitro at E11, the same time they would become dependent on target derived trophic support in vivo (Rodriguez-Tebar et al., 1989). Studies have revealed that BDNF supports the survival of developing E17 rat RGCs in vitro for at least 4 days, thus showing that RGCs isolated during the period of target innervation are responsive to BDNF (Johnson et al., 1986). Exogenous administration of BDNF into the superior colliculus of newborn hamsters at P3 does reduce the number of apoptotic RGCs by 13-15 fold after 20 hours (Ma et al., 1998). Furthermore, BDNF increased the survival of P2 RGCs over a 48 hour period (Kashiwagi et al., 2000). It has been suggested that the survival requirements of developing RGCs alter at the time of innervation (Ma et al., 1998). In this study, the short term in vitro survival of $\mathrm{E} 18$ rat RGCs treated with BDNF alone totalled only about $20 \%$, whereas almost $80 \%$ of these RGCs survived when tectal conditioned medium was added. This would indicate the importance of other tectal factors in RGC survival in addition to neurotrophin support. Interestingly however, no responsiveness to trophic factors was witnessed unless intracellular cAMP was 


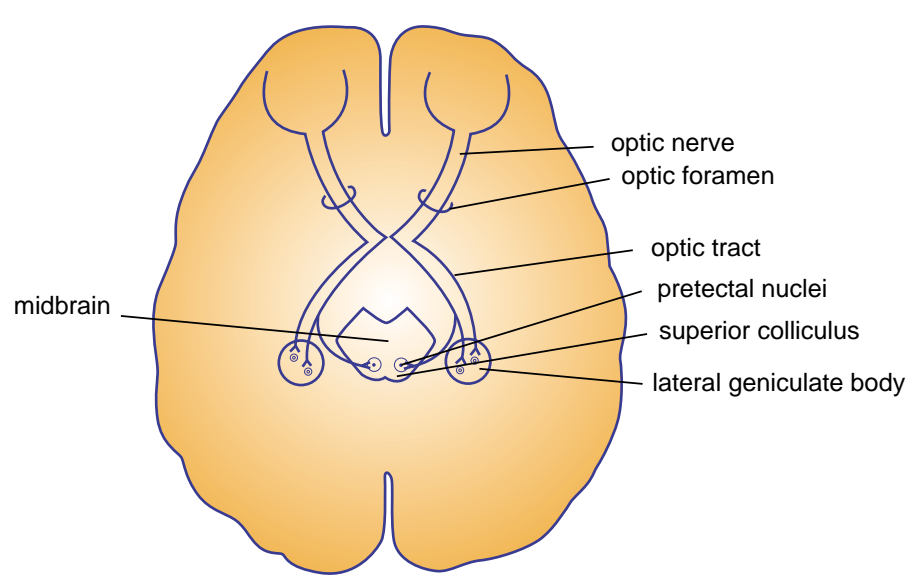

Fig. 3. Retinotectal projections of retinal ganglion cells (RGCs) in the vertebrate. $R G C s$ process and project information from the retina along the optic nerve and optic tract to visual centres such as the superior collicullis, with $30 \%$ of RGCs in the rat sending collaterals to the lateral geniculate nucleus. These retinal projections map the distinct topography of the retina to the visual centres.

elevated.

To complicate matters further, $\mathrm{BDNF}^{-/-}$mice have normal numbers of RGCs at birth (Cellerino and Kohler, 1997). One possible explanation for this phenomenon is that the protective effect of BDNF is merely transient. The fact that exogenous administration of BDNF to chick embroyos during the period of developmental RGC death did not reduce PCD further supports this theory (Drum et al., 1996). Thus the role of neurotrophic factors at the later stage of PCD is far from transparent and it is unclear whether neurotrophic factors are crucial to RGC survival at all during this latter period of $R G C$ death (Bahr, 2000). Findings indicating the positive survival effects of multiple factors on RGCs indicate a highly complex relationship between neurotrophic factors governing such development. It appears that the effects of single neurotrophins on RGC survival cannot be amply judged simply by analysing knockout models or applying relevant antibodies, as merely negating one mechanism may simply upregulate another pathway.

\section{Developmental apoptosis of retinal ganglion cells}

Apoptosis may be defined as an energy dependent form of autonomous cell death, in which the cell presides over its own fate. Indeed, it is now evident that living cells contain an inherent genomic ability to self-destruct at the behest of various stimuli (Bowen, 1993). With a propensity to occur in single cells, often amidst healthy neighbouring cells, apoptosis is marked by distinctive biochemical and morphological characteristics such as chromatin condensation, cell shrinkage, blebbing of the plasma membrane, DNA fragmentation and finally, fragmentation of the cell into membrane bound vesicles termed apoptotic bodies (Kerr et al., 1972) (Fig. 4). Ultimately these cells are phagocytosed by macrophages or neighbouring cells. Such sequelae are in contrast to those evident in necrotic cell death, which occur in the aftermath of a pathological insult. Necrotic cells swell, with rupture of intracellular organelles, disruption of the lysosomal and plasma membranes and result in generalised tissue inflammation. How- ever, these two forms of cell death are not necessarily mutually exclusive and may be viewed as occupying opposite ends of the same spectrum (Vecino et al., 2004, Spalding etal., 2005). Indeed there is growing evidence, as reported in this laboratory amongst others, of varying levels of cross talk between different death mediators, implying an ability to switch from one death mode to another. (Sanvicens et al., 2004, Gomez-Vicente et al., 2005, Bahr, 2000).

As far back as 1984, morphological changes indicative of apoptotic death were noticed in the nucleated layers of the developing retina (Young et al., 1984). Such observations included nuclear condensation, pyknosis and phagocytosis within the GCL during the first week of life. Biochemical techniques for measuring DNA fragmentation and plasma membrane alterations associated with apoptosis have confirmed that the mechanism of developmental RGC death is predominantly apoptotic. The purpose of such cell death in retinal ganglion cell development is akin to its purpose in general mammalian maturation: It aims to remove unnecessary structures (phylogenetic apoptosis), it seeks to control cell numbers (histogenetic apoptosis) and, as previously mentioned, plays a role in retinal sculpture (morphogenetic apoptosis) (Cecconi et al., 1998).

\section{Bcl-2 family and the mitochondrion}

The mitochondrion plays a significant role in apoptosis (Fig. 5). In addition to its everyday role as powerhouse of the cell, this double membraned organelle also harbours many proteins which have caspase dependent and independent roles, including cytochrome c, apoptosis inducing factor (AIF), Smac/Diablo, endonuclease $\mathrm{G}$ and $\mathrm{Omi} / \mathrm{H}$ trA2.

Within the CNS and the retina, the $b c /$-2gene family of proteins tightly controls mitochondrial membrane permeabilization (MMP) and the release of apoptogenic proteins. This family can be classified into three main subgroups on the basis of function and structure. In the first group, $\mathrm{Bcl}-2, \mathrm{Bcl}-\mathrm{X}_{\mathrm{L}}, \mathrm{Mcl}-1, \mathrm{~A} 1$ and $\mathrm{Bcl}-\mathrm{w}$ exhibit anti-apoptotic activity and commonly possess four conserved motifs, known as $\mathrm{Bcl}-2$ homology $(\mathrm{BH})$ domains. $\mathrm{Bcl}-2$ and $\mathrm{Bcl}-\mathrm{X}_{\mathrm{L}}$ have been shown to be involved in controlling the release of cytochrome $\mathrm{c}$ from the mitochondrion (Kluck et al., 1997, Yang et al., 1997, Vander Heiden et al., 1997). These two proteins may form heterodimers with Bax and Bak via the $\mathrm{BH}$ domains to neutralise their proapoptotic function.

The second group consists of the multi-domain pro-apoptotic proteins $\mathrm{Bax}$, Bak and $\mathrm{Bcl}-\mathrm{X}_{\mathrm{S}}$, which possess $\mathrm{BH} 1,2$ and 3 domains. The importance of Bax and Bak proteins has been demonstrated by Bax/Bak double knockouts. The majority of Bax/ Bak deficient animals do not undergo sufficient developmental apoptosis and thus die perinatally (Lindsten et al., 2000). Mouse embryonic fibroblasts (MEFs) isolated from embryos of these animals fail to undergo MMP and subsequent apoptosis (Wei et al., 2001). After oligomerization, these BCL-2 proteins subsequently insert into the outer mitochondrial membrane, forming pores to allow the passage of proteins to the cytosol.

The third group, the BH3 domain-only group, includes Bim, Bid, Bik, Bad, DP5/Hrk, Spike, Puma and Noxa (Danial and Korsmeyer, 2004). These proteins act upstream of MMP as sentinels of specific apoptotic stimuli. BH3-only proteins can be regulated at both the transcriptional and post-translational level in neurons to induce apoptosis (Ham et al., 2005, Ley et al., 2005, 
Willis and Adams 2005). By displacing distinct members of the anti-apoptotic Bcl-2 family which bind Bax/Bak, BH3 proteins promote the release of Bax, enabling it to induce mitochondrial permeabilization (Chen et al., 2005, Letai et al., 2002). This enables Bax/Bak to oligomerize and induce mitochondrial permeabilisation. It has also been demonstrated that the inhibition of anti-apoptotic proteins is insufficient to induce apoptosis unless a direct activator of Bax or Bak such as Bid or Bim is present (Kuwana et al., 2005). To date, animal knockout studies have shown that none of the BH3-only proteins is essential for developmental cell death in the nervous system, indicating there may be a level of redundancy among these proteins during this period (Akhtar et al., 2004).

Pro and anti-apoptotic Bcl-2 proteins are differentially expressed in the developing and mature CNS. Bax is highly expressed at the inception of developmental cell death, with subsequent down regulation in mature neuronal tissue (Vekrellis et al., 1997). Studies on baxknockout mice have demonstrated that the absence of this death-promoting gene during development has a mild but discernible effect on the adult retina, resulting in a thickened inner neuroblastic layer and increasing the cell number in the GCL (Pequignot et al., 2003). It has been reported that abundant cell death is evident as early as E11.5 in the developing layers of both wild-type and $B a X^{/-}$mice and continues to be observed until P1 (White et al., 1998). However this study further revealed that TUNEL positive cells were noticeably absent in the $\mathrm{RGC}$ layer in Bax null mice between $\mathrm{P} 1$ and $\mathrm{P} 4$, resulting in more

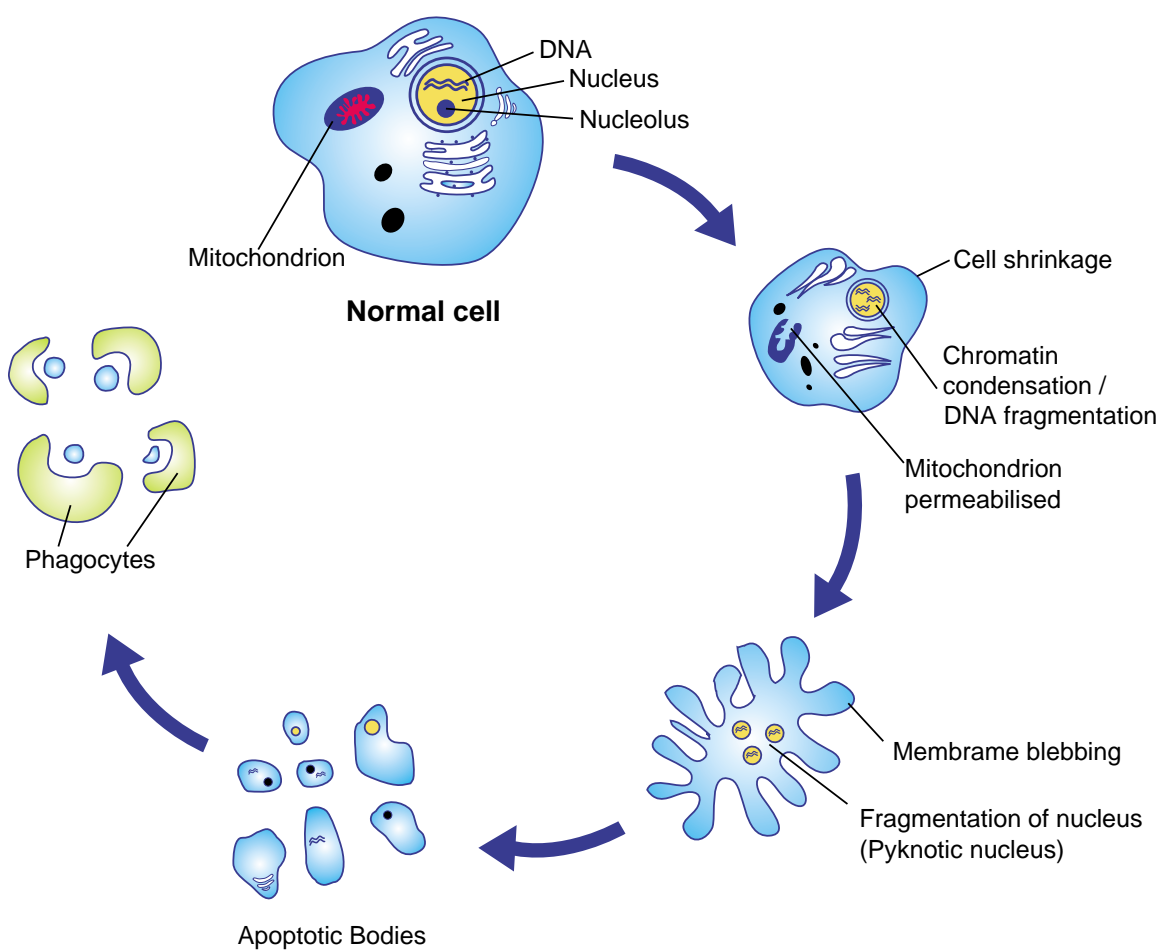

Fig. 4. Cell undergoing apoptosis. Apoptosis is marked by distinctive biochemical and morphological characteristics. These include chromatin condensation, cell shrinkage, blebbing of the plasma membrane, DNA and nuclear fragmentation and finally, cell fragmentation into membrane bound vesicles termed "apoptotic bodies", which are then phagocytosed by macrophages or neighbouring cells. than double the usual numbers of RGCs in the post mitotic retina. Thus it would seem that while embryonic developmental cell death from E11.5 is Bax-independent, Bax appears to be necessary for developmental RGC death in the post-natal retina. These findings highlight not only the fundamental importance of PCD for the construction of a normal, functional retina, but also the reliance on Bax involvement in the process of developmental RGC death (Mosinger Ogilvie et al., 1998, Pequignot et al. 2003, White etal., 1998). In Bax ${ }^{-/-B^{-1-}}$ double knockout mice, histology has revealed increased numbers of neurons within the GCL of the mature retina compared to the wildtype (Hahn et al., 2003). Indeed, at P7, a peak period of developmental apoptosis, this study revealed that there is almost a complete absence of TUNEL positive apoptotic cells in the retina of this knockout model.

$\mathrm{Bcl}-2$ is also highly expressed during embryonic and postnatal development of the CNS, including in the GCL, but decreased expression coincides with maturity (Chen et al., 2004, Isenmann et al., 1997, Levin et al., 1997). Mice deficient for Bcl2 are viable at birth and while some may survive to adulthood, most will die prior to P14 (Michaelidis et al., 1996). Bcl-2 deficient mice exhibit loss of about one third of their RGCs after the period of naturally occurring cell death (Cellerino et al., 1999), indicating an essential role for Bcl-2 in survival of post developmental PCD neurons but not for developmental PCD itself. Mice deficient for the anti-apoptotic gene, $\mathrm{Bcl}-\mathrm{X}_{\mathrm{L}}$, experience embryonic lethality as early as E13 due to massive apoptosis of undeveloped neurons (Motoyama et al., 1995). Therefore while no description of a retinal phenotype is available, these findings reveal a crucial role for $B c l-X_{L}$ in modulating developmental neuronal apoptosis.

\section{Executioners of retinal ganglion cell death}

A family of cysteine aspartyl-specific proteases called caspases, of which there are 15 mammalian members, has emerged as central regulators of apoptosis. These enzymes are present in the cell as inactive zymogens and become active by proteolytic processing or induced proximity. Caspases, once activated, are involved in an ordered cascade, which culminates in the proteolysis of key structural and nuclear components and the eventual destruction of the cell (Earnshaw et al., 1999). Two pathways that activate one of the major executioners of cell death, caspase3 , have been identified. These include an extrinsic pathway involving death-promoting receptors and ligands and an intrinsic pathway that is regulated by a series of specific deathpromoting molecules released from the mitochondrion (Fig. 5).

The extrinsic (death receptor) pathway involves the activation of cell surface death receptors which are members of the tumour necrosis factor (TNF) receptor gene superfamily. These receptors contain a cytoplasmic death domain that, once activated by the ligation of an extrinsic factor, results in the formation of a death-inducing signalling complex 


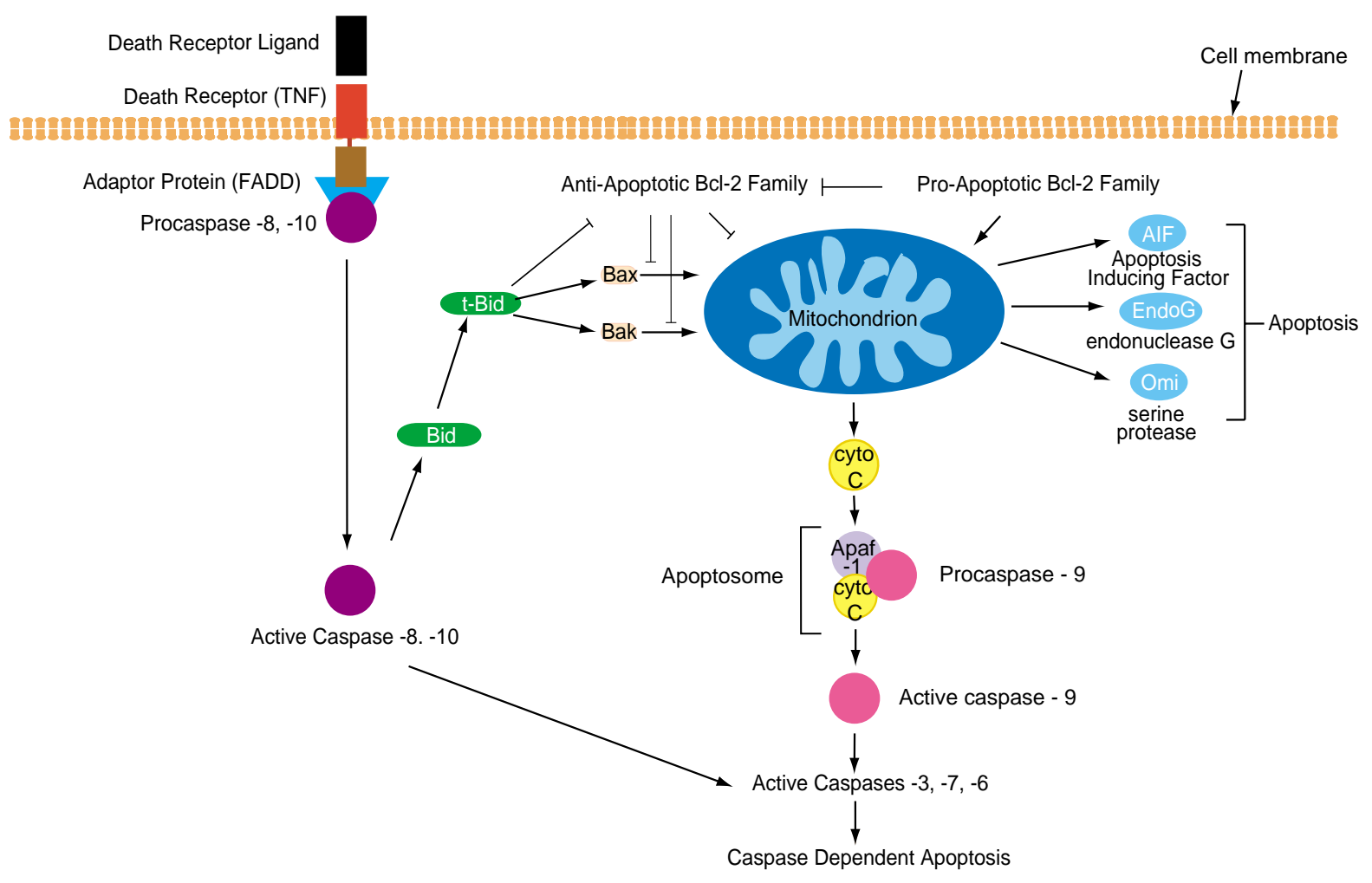

Fig. 5. Pathways of apoptosis. There are two major apoptotic pathways in the cell. The extrinsic pathway (left) involves the binding of extracellular ligands to death-promoting receptors, resulting in the formation of a death inducing complex (DISC). DISC, through the adaptor Fas-associated death domain (FADD) protein, then recruits procaspase-8, which in turn activates caspase-8. The intrinsic pathway (centre) is regulated by a series of specific death-promoting molecules released from the mitochondrion. Pro and anti-apoptotic BCL-2 family members compete at the mitochondrion surface to control the release of cytochrome-c. Once released, cytochrome-c associates with Apaf-1 and procaspase-9, in a dATP dependent manner, to form the apoptosome, which then activates caspase-9. The extrinsic and intrinsic pathways share a common end point at the level of caspase-3 activation. Interaction between these pathways is provided by caspase-8 triggered cleavage of Bid. Interaction of Bid with Bax or Bak at the mitochondrial outer membrane results in cytochrome-c release. The anti-apoptotic BCL-2 family can prevent such release by direct interaction with Bax and/or Bak. Further caspase-independent pathways (right) may occur through the release of apoptogenic molecules such as Apoptosis-Inducing Factor (AIF), Endonuclease $G$ (EndoG) and Omi/HtrA2.

(DISC) in the cell (Ashkenazi and Dixit, 1998). This complex may activate procaspase- 8 by dimerization via the adaptor molecule Fas activated death domain (FADD) (Boatright et al., 2003). Activated caspase-8 may then cleave and trigger the executionary procaspase-3 (Ashkenazi and Dixit, 1998).

The intrinsic (mitochondrial) pathway is activated by various apoptotic stimuli and involves the release of cytochrome-c from the mitochondrion to the cytosol, which in turn activates a proteolytic cascade (Li et al., 1997). Cytochrome c interacts with the C-terminal WD-40 repeats of the adaptor molecule Apaf-1, resulting in a conformational change that allows dATP/ATP to bind. This resulting multimeric complex then recruits caspase- 9 to form an active holoenzyme, the apoptosome (Jiang and Wang, 2004, Acehan et al., 2002). Caspase-9 cleaves executioner caspases, such as caspase- 7 and caspase- 3 . Activated caspase- 3 cleaves caspase- 2 and caspase- 6 , with caspase- 6 capable of cleaving caspase-8 and-10 (Slee et al., 1999).

Crosstalk between the extrinsic and intrinsic pathways is mediated by truncated Bid molecules through the actions of caspase-8. This enzyme has been reported to cleave Bid, result- ing in subsequent translocation of the c-terminal to the mitochondrion and promote cytochrome-c release through Bax activation (Li et al., 1998, Luo et al., 1998). Caspase activation may be endogenously inhibited by the action of inhibitor of apoptosis proteins (IAPs), of which XIAP, C-IAP1 and c-IAP2 can directly inhibit caspases. By adopting distinct mechanisms, XIAP inhibits caspases $-3,-7$ and -9 via their baculovirus IAP repeat (BIR) domains (Salvesen and Duckett, 2002). IAPs themselves can be antagonized by the actions of IAP antagonist proteins such as Smac, its mouse homologue DIABLO and the serine protease Omi/HtrA2. These proteins, which are released with cytochromec from the permeabilised mitochondrion, can displace caspases from IAPs by binding to the BIR domains via the AVP (I/S) binding motif (Du et al., 2000, Verhagen et al., 2000, Suzuki et al., 2001, Salvesen and Duckett, 2002).

Caspases play a pivotal role in several paradigms of adult RGC death (McKinnon et al., 2002, Kermer et al., 1999). There is also a plethora of evidence confirming the central role of caspases in developmental cell death in the GCL. Analysis of knockout animals has been fundamental in identifying a role for Apaf- 1 and 
caspase family members in developmental neuronal apoptosis in vivo. Apaf-1 null mice exhibit retinal hyperplasia and alterations of the lens (Cecconi et al., 1998), while caspase-9 null mice display an excessive accumulation of most CNS cells (Hakem et al., 1998). Mice lacking caspase3 exhibit decreased apoptosis of CNS neurons resulting in hypertrophy of the brain and premature lethality (Kuida etal., 1996). While this makes it impossible to study the effects of caspase-3 ablation in the mature CNS and retina, developmental apoptosis may be investigated. A recent study by Zeiss and colleagues has explored the role of caspase-3 in post natal retinal development (Zeiss et al., 2004). In this study, active caspase-3 immunopositive cells were observed in the developing GCL of neonatal caspase-3 sufficient mice. However, it was noted that similar staining was absent in the GCL of caspase- $3^{-/-}$ mice, despite the presence of dying cells. It was also noted that ablation of caspase-3 did not completely inhibit developmental apoptosis but resulted only in a temporary delay, indicating the existence of an alternative, possibly compensatory, caspase-3 independent pathway.

Caspases have also been found to be necessary for RGC development in the embroyonic chick retina. Studies on early PCD in the retinal neuroepithelium of chick embryos from E2-E6 provide evidence in favour of a role for caspase3 in developmental apoptosis (Mayordomo et al., 2003). In this study, TUNEL-positive cells co stained for active caspase- 3 and administration of the caspase inhibitors z-DEVD-fmk and Boc-Dfmk reduced the number of TUNEL positive cells by $50 \%$ in just 6 hours. Continued treatment with these inhibitors resulted in a minor widening of the central neural retina, with simultaneous enlargement of the GCL and increase in RGC numbers. These results demonstrate the occurrence of caspase-dependent PCD in early embryonic retinal development. Furthermore, analysis in this laboratory has revealed the presence at P2-6 of cleaved caspase- 3 and -9 in TUNEL positive cells of the developing mouse ganglion cell layer (McKernan et al., 2006) (Fig. 6 (i)). Thus it appears that the intrinsic mitochondrial pathway is activated during postnatal development.

Interestingly, the susceptibility of RGCs to apoptosis induced by axotomy appears to be age dependent. It has been reported that whilst adult rat RGC death in vivo post axotomy is not seen until day 3 post operatively and does not peak until day $7, \mathrm{RGC}$ death in the neonatal retina post superior colliculus ablation is greatest at 24 hours and is complete by 48 hours (Spalding et al., 2005). Investigations in this laboratory have not only noted an age-dependent susceptibility to developmental cell death within the mouse GCL in a retinal explant model, but also found a similar susceptibility to death

(i)

(ii)

(iii)

(iv)

GCL

INL

ONL
P6

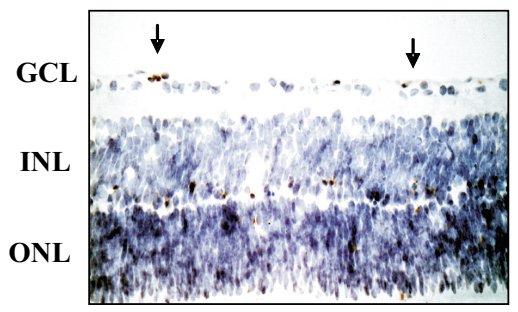

P6 A23187 6 hr

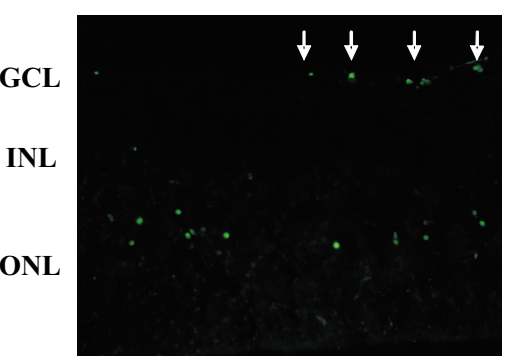

P6
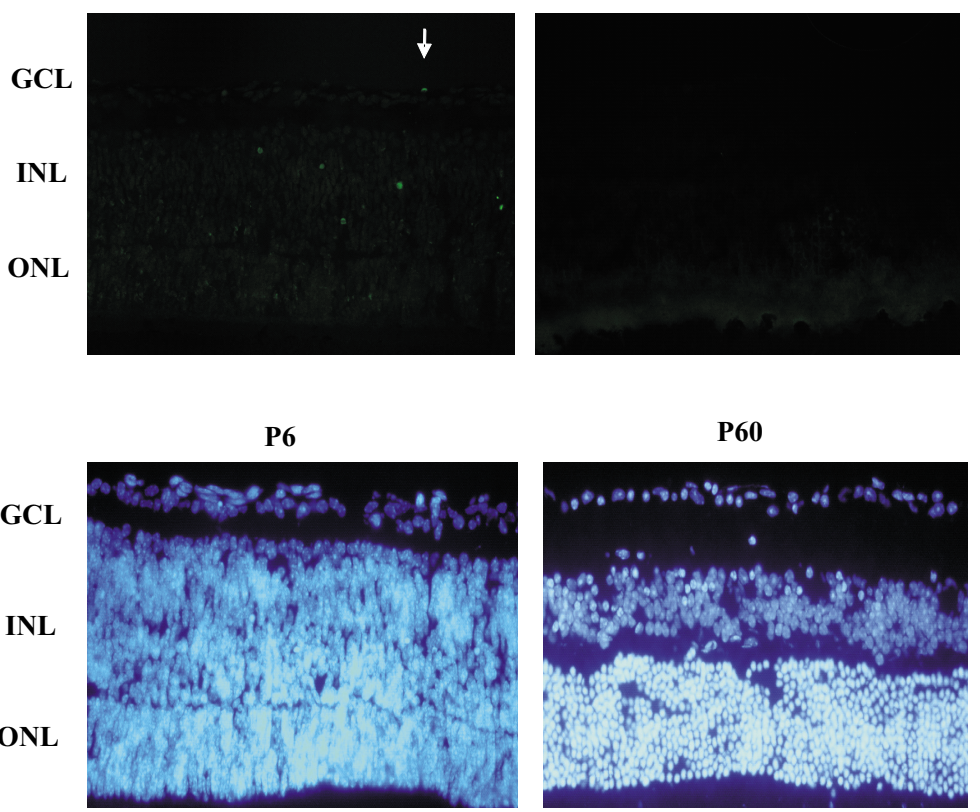

GCL

INL

Fig. 6. Developmental apoptosis and differential susceptibility of the mouse ganglion cell layer (GCL) to cell death. (i) Immunohistochemical staining of P6 retinal sections for cleaved caspase-3 shows evidence of the active caspase fragment (black arrows) in the GCL. However this staining is not present within the GCL at P60. (ii) Positive TUNEL staining indicates that P6 cells in the GCL are markedly more susceptible to apoptotic cell death following 6 hours of treatment with $1 \mu \mathrm{M}$ calcium ionophore A23187 (white arrows), than A23187 treated P60 cells. (iii) Spontaneous developmental cell death occurs in the GCL of the P6 retinas, as evidenced by the presence of TUNEL positive cells (white arrows). However this developmental death is absent at P60. (iv) Hoechst stained nuclei of P6 and P60 retinal sections are shown.

following axotomy and excitotoxic stimuli in this model (McKernan et al., 2006) (Fig. 6(ii)). Furthermore, we have found that approximately $90 \%$ of isolated rat RGCs within dissociated retinal cell cultures at P6 are susceptible to apoptotic death in vitro when treated with calcium ionophore, A23187, over a 24-hour period. 
However, their adult counterparts are far more resistant to such a stimulus (unpublished data). This difference in susceptibility correlated with a developmental downregulation of pro-apototic proteins including Apaf-1 and caspase-3 in the adult GCL (McKernan et al., 2006). A similar phenomenon has previously been noted in a rat model of traumatic brain injury, where it has also been reported that these proteins are markedly reduced in the mature cortex (Yakovlev et al., 2001). Thus reactivation of these genes is required for neuronal apoptotic injury to occur in the adult brain. The results of this study, allied to findings from this laboratory, suggest that developing RGCs are primed to die in order for adequate physiological development in the GCL to occur (Fig. 6(iii)). However once this development is complete, this default apoptotic pathway is shut down and adult neurons then adopt a protective mechanism against any potential damaging insults (Benn and Woolf, 2004).

While caspases clearly play a central role in many instances of apoptosis, there is a growing body of evidence that apoptosis can occur under certain conditions in a caspase-independent manner. Whilst a number of alternative proteases have been reported to carry out the demolition of the cell resulting in alternative morphology to conventional caspase dependent cell death, evidence of similar occurrences in developmental RGC demise is sparse. (Leist and Jaattela, 2001, Tezel and Yang, 2004). A recent study by Spalding et al. has reported that ablation of the superior colliculus in neonatal rats (P4) results in notable RGC death within 24 hours. As this death is not blocked by specific or general caspase inhibitors, the authors suggest the presence of a caspase independent pathway in the neonatal mouse (Spalding et al., 2005).

\section{Conclusion}

The retina represents one of the most accessible aspects of the central nervous system for analysis and research and recent years have witnessed the elucidation of many of the pathways central to neurogenesis and developmental apoptosis within the nascent RGC population. However certain fundamental areas still remain to be explored in full and future investigations will need to examine the roles of both neurotrophins and caspase independent pathways, in order to gain a more transparent perspective on RGC growth patterns.

\section{Summary}

This review examines the maturation of the retinal ganglion cell (RGC) population within the nascent retina. Apoptosis, a form of programmed cell death prevalent throughout the developing central nervous system (CNS), is evident in the growth of RGCs within the ganglion cell layer. These cells provide an accessible and illuminating platform to elucidate the apoptotic pathways present in the developing CNS and the role this form of cell death plays in RGC growth. This article focuses on the seminal stages of RGC development and the role played by neurotrophic factors and apoptosis in this process.

KEYWORDS: apoptosis, development, retinalganglion cell, retina, neurotrophin

\section{Acknowledgements}

We wish to acknowledge funding from Science Foundation Ireland, Health Research Board and the Irish Research Council for Science Engineering and Technology (IRCSET). We wish to acknowledge members of the laboratory for critical reading of the manuscript and helpful discussions. This work was supported by the Health Research Board of Ireland, Science Foundation Ireland and the Irish Research Council for Science Engineering and Technology under the Embark Initiative.

\section{References}

ACEHAN, D., JIANG, X., MORGAN, D. G., HEUSER, J. E., WANG, X., AKEY, C. W. (2002) Three-dimensional structure of the apoptosome: implications for assembly, procaspase-9 binding and activation Mol Ce//9: 423-32.

AKHTAR, R.S., NESS, J.M. and ROTH, K.A. (2004). Bcl-2 family regulation of neuronal development and neurodegeneration. Biochim Biophys Acta 1644: 189-203.

ASHKENAZI, A. and DIXIT, V.M. (1998). Death receptors: Signaling and modulation. Science 281: 1305-8.

AUSTIN, C.P., FELDMAN, D.E., IDA, J.A., JR. and CEPKO, C.L. (1995). Vertebrate retinal ganglion cells are selected from competent progenitors by the action of notch. Development 121: 3637-50.

BAHR, M. (2000). Live or let die - retinal ganglion cell death and survival during development and in the lesioned adult CNS. Trends Neurosci23: 483-90.

BENN, S.C. and WOOLF, C.J. (2004). Adult neuron survival strategies-slamming on the brakes. Nat Rev Neurosci5: 686-700.

BIBEL, M. and BARDE, Y.A. (2000). Neurotrophins: Key regulators of cell fate and cell shape in the vertebrate nervous system. Genes Dev 14: 2919-37.

BOATRIGHT, K.M., RENATUS, M., SCOTT, F.L., SPERANDIO, S., SHIN, H., PEDERSEN, I.M., RICCI, J.E., EDRIS, W.A., SUTHERLIN, D.P., GREEN, D.R. et al. (2003). A unified model for apical caspase activation. Mol Cel/11: 529-41.

BOVOLENTA, P., FRADE, J.M., MARTI, E., RODRIGUEZ-PENA, M.A., BARDE, Y.A. and RODRIGUEZ-TEBAR, A. (1996). Neurotrophin-3 antibodies disrupt the normal development of the chick retina. JNeurosci 16: 4402-10.

BOWEN, I.D. (1993). Apoptosis or programmed cell death? Cel/ Biol/nt 17: 365-80.

BROWN, N.L., PATEL, S., BRZEZINSKI, J. and GLASER, T. (2001). Math5 is required for retinal ganglion cell and optic nerve formation. Development 128 : 2497-508.

BUHL, E.H. and DANN, J.F. (1988). Morphological diversity of displaced retinal ganglion cells in the rat: A lucifer yellow study. J Comp Neuro/269: 210-8.

BUNT, A.H. and LUND, R.D. (1974). Vinblastine-induced blockage of orthograde and retrograde axonal transport of protein in retinal ganglion cells. Exp Neurol 45: 288-97.

CARTER, B.D. and LEWIN, G.R. (1997). Neurotrophins live or let die: Does p75(ntr) decide? Neuron 18: 187-190.

CECCONI, F., ALVAREZ-BOLADO, G., MEYER, B.I., ROTH, K.A. and GRUSS, P. (1998). Apaf1 (ced-4 homolog) regulates programmed cell death in mammalian development. Cel/94: 727-37.

CELLERINO, A. and KOHLER, K. (1997). Brain-derived neurotrophic factor/ neurotrophin-4 receptor trkb is localized on ganglion cells and dopaminergic amacrine cells in the vertebrate retina. J Comp Neuro/386: 149-60.

CELLERINO, A., MICHAELIDIS, T., BARSKI, J.J., BAHR, M., THOENEN, H. and MEYER, M. (1999). Retinal ganglion cell loss after the period of naturally occurring cell death in bcl-2-/- mice. Neuroreport 10: 1091-5.

CEPKO, C.L., AUSTIN, C.P., YANG, X., ALEXIADES, M. and EZZEDDINE, D. (1996). Cell fate determination in the vertebrate retina. Proc Nat/ Acad Sci USA 93: $589-95$.

CHEN, L., WILLIS, S.N., WEI, A., SMITH, B. J., FLETHCHER, J.I., HINDS, M.G., COLMAN, P.M., DAY, C.L.,ADAMS, J.M. and HUANG, D. (2005) Differential targeting of prosurvival $\mathrm{Bcl}-2$ proteins by their $\mathrm{BH} 3$-only ligands allows complementary apoptotic function. Mol Cel/ 17: 393-403.

DALLIMORE, E.J., CUI, Q., BEAZLEY, L.D. and HARVEY, A.R. (2002). Postnatal innervation of the rat superior colliculus by axons of late-born retinal ganglion cells. Eur J Neurosci 16: 1295-304. 
DANIAL, N.N. and KORSMEYER, S.J. (2004). Cell death: Critical control points. Cel/116: 205-19.

DANIAS, J., SHEN, F., GOLDBLUM, D., CHEN, B., RAMOS-ESTEBAN, J., PODOS, SM., MITTAG, T. (2002) Cytoarchiture of the retinal ganglion cells in the rat. Invest Ophthalmol Vis Sci 43: 587-594.

DONOVAN, M. and COTTER, T.G. (2004). Control of mitochondrial integrity by bcl2 family members and caspase-independent cell death. Biochim Biophys Acta 1644: 133-47.

DREHER, B., SEFTON, A.J., NI, S.Y. and NISBETT, G. (1985). The morphology, number, distribution and central projections of class i retinal ganglion cells in albino and hooded rats. Brain Behav Evo/26: 10-48.

DRUM, K., FORBES, M.E., WANG, S.W. and JOHNSON, J.E. (1996). Treatment with bdnf does not prevent normal chick rgc death in ovo. Soci Neuroscience Abstr22: 397.25 .

DU, C., FANG, M., LI, Y., LI, L. and WANG, X. (2000). Smac, a mitochondrial protein that promotes cytochrome $\mathrm{c}$-dependent caspase activation by eliminating iap inhibition. Ce//102: 33-42.

EARNSHAW, W.C., MARTINS, L.M. and KAUFMANN, S.H. (1999). Mammalian caspases: Structure, activation, substrates and functions during apoptosis. Annu Rev Biochem 68: 383-424.

FARAH, M.H. and EASTER, S.S., JR. (2005). Cell birth and death in the mouse retinal ganglion cell layer. J Comp Neuro/489: 120-34.

FORRESTER, J. and PETERS, A. (1967) Nerve fibres in the optic nerve of rat. Nature 214: 245-247.

FRADE, J.M. and BARDE, Y.A. (1999). Genetic evidence for cell death mediated by nerve growth factor and the neurotrophin receptor p75 in the developing mouse retina and spinal cord. Development 126: 683-90.

FRADE, J.M., BOVOLENTA, P., MARTINEZ-MORALES, J.R., ARRIBAS, A., BARBAS, J.A. and RODRIGUEZ-TEBAR, A. (1997). Control of early cell death by bdnf in the chick retina. Development 124: 3313-20.

FRADE, J.M., RODRIGUEZ-TEBAR, A. and BARDE, Y.A. (1996). Induction of cell death by endogenous nerve growth factor through its $p 75$ receptor. Nature 383 : 166-8.

GALLI-RESTA, L. and ENSINI, M. (1996). An intrinsic time limit between genesis and death of individual neurons in the developing retinal ganglion cell layer. $J$ Neurosci 16: 2318-24.

GAN, L., WANG, S.W., HUANG, Z. and KLEIN, W.H. (1999). Pou domain factor brn$3 \mathrm{~b}$ is essential for retinal ganglion cell differentiation and survival but not for initial cell fate specification. Dev Bio/210: 469-80.

GARNER, A.S., MENEGAY, H.J., BOESHORE, K.L., XIE, X.Y., VOCI, J.M., JOHNSON, J.E. and LARGE, T.H. (1996). Expression of trkb receptor isoforms in the developing avian visual system. J Neurosci 16: 1740-52.

GOMEZ-VICENTE, V., DONOVAN, M. and COTTER, T.G. (2005). Multiple death pathways in retina-derived $661 \mathrm{w}$ cells following growth factor deprivation: Crosstalk between caspases and calpains. Cell Death Differ 12: 796-804.

GREEN, D.R. and KROEMER, G. (2004). The pathophysiology of mitochondrial cell death. Science 305: 626-9.

HAHN, P., LINDSTEN, T., YING, G.S., BENNETT, J., MILAM, A.H., THOMPSON, C.B. and DUNAIEF, J.L. (2003). Proapoptotic bcl-2 family members, bax and bak, are essential for developmental photoreceptor apoptosis. Invest Ophthalmo/ Vis Sci 44: 3598-605.

HAKEM, R., HAKEM, A., DUNCAN, G.S., HENDERSON, J.T., WOO, M., SOENGAS, M.S., ELIA, A., DE LA POMPA, J.L., KAGI, D., KHOO, W. et al. (1998). Differential requirement for caspase 9 in apoptotic pathways in vivo. Cel/94: 339-52.

HAM, J., TOWERS, E., GILLEY, J., TERZANO, S. and RANDALL, R. (2005). Bh3only proteins: Key regulators of neuronal apoptosis. Cell Death Differ 12: 101520.

HERZOG, K.H. and VON BARTHELD, C.S. (1998). Contributions of the optic tectum and the retina as sources of brain-derived neurotrophic factor for retinal ganglion cells in the chick embryo. J Neurosci 18: 2891-906.

ISENMANN, S., KRETZ, A. and CELLERINO, A. (2003). Molecular determinants of retinal ganglion cell development, survival and regeneration. Prog Retin Eye Res 22: 483-543.

ISENMANN, S., WAHL, C., KRAJEWSKI, S., REED, J.C. and BAHR, M. (1997). Up- regulation of bax protein in degenerating retinal ganglion cells precedes apoptotic cell death after optic nerve lesion in the rat. Eur J Neurosci9: 176372.

JIANG, X., WANG, X., (2004). Cytochrome-c mediated apoptosis. Annu Rev Biochem 73: 87-106

JOHNSON, J.E., BARDE, Y.A., SCHWAB, M. and THOENEN, H. (1986). Brainderived neurotrophic factor supports the survival of cultured rat retinal ganglion cells. J Neurosci6: 3031-8.

KAPLAN, D.R. and MILLER, F.D. (2000). Neurotrophin signal transduction in the nervous system. Curr Opin Neurobio/10: 381-91.

KASHIWAGI, F., KASHIWAGI, K., IIZUKA, Y. and TSUKAHARA, S. (2000). Effects of brain-derived neurotrophic factor and neurotrophin-4 on isolated cultured retinal ganglion cells: Evaluation by flow cytometry. Invest Ophthalmol Vis Sci 41: 2373-7.

KERR, J.F., WYLIE A.H., CURRIE, A.R. (1972). Apoptosis: a basic biological phenomenon with wide-ranging implications in tissue kinetics $\mathrm{Br} J$ Cancer 26:4:239-57

KERMER, P., KLOCKER, N., LABES, M., THOMSEN, S., SRINIVASAN, A. and BAHR, M. (1999). Activation of caspase-3 in axotomized rat retinal ganglion cells in vivo. FEBS Lett 453: 361-4.

KLUCK, R.M., BOSSY-WETZEL, E., GREEN, D.R. and NEWMEYER, D.D. (1997). The release of cytochrome $c$ from mitochondria: A primary site for bcl-2 regulation of apoptosis. Science 275: 1132-6.

KUIDA, K., ZHENG, T.S., NA, S., KUAN, C., YANG, D., KARASUYAMA, H., RAKIC, P. and FLAVELL, R.A. (1996). Decreased apoptosis in the brain and premature lethality in cpp32-deficient mice. Nature 384: 368-72.

KUWANA, T., BOUCHIER-HAYES, L., CHIPUK, J.E., BONZON, C., SULLIVAN, B.A., GREEN, D.R. and NEWMEYER, D.D. (2005). Bh3 domains of bh3-only proteins differentially regulate bax-mediated mitochondrial membrane permeabilization both directly and indirectly. Mol Cel/17: 525-35.

LEIST, M. and JAATTELA, M. (2001). Four deaths and a funeral: From caspases to alternative mechanisms. Nat Rev Mol Cell Bio/2: 589-98.

LETAI, A., BASSIK, M. C., WALENSKY, L. D., SORCINELLI, M. D., WEILER, S., KORSMEYER, S. J. (2002). Distinct BH3 domains either sensitize or activate mitochondrial apoptosis, serving as prototype cancer therapeutics. Cancer Cell 2: 183-92.

LEVIN, L.A., SCHLAMP, C.L., SPIELDOCH, R.L., GESZVAIN, K.M. and NICKELLS, R.W. (1997). Identification of the bcl-2 family of genes in the rat retina. Invest Ophthalmol Vis Sci38: 2545-53.

LEY, R., EWINGS, K.E., HADFIELD, K. and COOK, S.J. (2005). Regulatory phosphorylation of bim: Sorting out the erk from the jnk. Cel/ Death Differ 12: 1008-14.

LI, P., NIJHAWAN, D., BUDIHARDJO, I., SRINIVASUlA, S. M., AHMAD, M., ALNEMRI, E. S., WANG, X. (1997). Cytochrome c and dATP-dependent formation of Apaf- $1 /$ caspase- 9 complex initiates an apoptotic protease cascade. Cel/91: 479-89.

LI, H., ZHU, H., XU, C.J. and YUAN, J. (1998). Cleavage of bid by caspase 8 mediates the mitochondrial damage in the fas pathway of apoptosis. Cel/94: 491-501.

LINDSTEN, T., ROSS, A.J., KING, A., ZONG, W.X., RATHMELL, J.C., SHIELS, H.A., ULRICH, E., WAYMIRE, K.G., MAHAR, P., FRAUWIRTH, K. et al. (2000). The combined functions of proapoptotic bcl-2 family members bak and bax are essential for normal development of multiple tissues. Mol Cel/6: 1389-99.

LUND, R.D. and BUNT, A.H. (1976). Prenatal development of central optic pathways in albino rats. J Comp Neuro/ 165: 247-64.

LUO, X., BUDIHARDJO, I., ZOU, H., SLAUGHTER, C. and WANG, X. (1998). Bid, a bcl2 interacting protein, mediates cytochrome $c$ release from mitochondria in response to activation of cell surface death receptors. Cel/94: 481-90.

MA, Y.T., HSIEH, T., FORBES, M.E., JOHNSON, J.E. and FROST, D.O. (1998). Bdnf injected into the superior colliculus reduces developmental retinal ganglion cell death. J Neurosci 18: 2097-107.

MARQUARDT, T., ASHERY-PADAN, R. andREJEWSKI, N., SCARDIGLI, R., GUILLEMOT, F. and GRUSS, P. (2001). Pax6 is required for the multipotent state of retinal progenitor cells. Cel/105: 43-55.

MASLIM, J., WEBSTER, M. and STONE, J. (1986). Stages in the structural 
differentiation of retinal ganglion cells. J Comp Neuro/254: 382-402.

MAYORDOMO, R., VALENCIANO, A.I., DE LA ROSA, E.J. and HALLBOOK, F. (2003). Generation of retinal ganglion cells is modulated by caspase-dependent programmed cell death. Eur J Neurosci 18: 1744-50.

MCKERNAN, D.P., CAPLIS, C., DONOVAN, M., O'BRIEN, C.J. and COTTER, T.G. (2006). Age-dependent susceptibility of the retinal ganglion cell layer to cell death. Invest Ophthalmol Vis Sci47 (3): 807-814.

MCKINNON, S.J., LEHMAN, D.M., KERRIGAN-BAUMRIND, L.A., MERGES, C.A., PEASE, M.E., KERRIGAN, D.F., RANSOM, N.L., TAHZIB, N.G., REITSAMER, H.A., LEVKOVITCH-VERBIN, H. et al. (2002). Caspase activation and amyloid precursor protein cleavage in rat ocular hypertension. Invest Ophthalmol Vis SCi 43: 1077-87.

MICHAELIDIS, T.M., SENDTNER, M., COOPER, J.D., AIRAKSINEN, M.S., HOLTMANN, B., MEYER, M. and THOENEN, H. (1996). Inactivation of bcl-2 results in progressive degeneration of motoneurons, sympathetic and sensory neurons during early postnatal development. Neuron 17: 75-89.

MOSINGER OGILVIE J., DECKWORTH T.L., KNUDSON C.M., KORSMEYER S.J. (1998) Suppression of developmental retinal cell death but not of photoreceptor degeneration in Bax-deficient mice. Invest Ophthalmol Vis Sci39: 1713-20.

MOTOYAMA, N., WANG, F., ROTH, K.A., SAWA, H., NAKAYAMA, K., NEGISHI, I., SENJU, S., ZHANG, Q., FUJII, S. and ET AL. (1995). Massive cell death of immature hematopoietic cells and neurons in bcl-x-deficient mice. Science 267: 1506-10.

$\mathrm{MU}, \mathrm{X}$. and KLEIN, W.H. (2004). A gene regulatory hierarchy for retinal ganglion cell specification and differentiation. Semin Cell Dev Bio/15: 115-23.

PEQUIGNOT, M.O., PROVOST, A.C., SALLE, S., TAUPIN, P., SAINTON, K.M., MARCHANT, D., MARTINOU, J.C., AMEISEN, J.C., JAIS, J.P. and ABITBOL, M. (2003). Major role of bax in apoptosis during retinal development and in establishment of a functional postnatal retina. Dev Dyn 228: 231-8.

PERRY, V.H. (1981). Evidence for an amacrine cell system in the ganglion cell layer of the rat retina. Neuroscience 6: 931-44.

PERRY, V.H. and COWEY, A. (1982). A sensitive period for ganglion cell degeneration and the formation of aberrant retino-fugal connections following tectal lesions in rats. Neuroscience 7: 583-94.

PERRY, V.H., HENDERSON, Z. and LINDEN, R. (1983). Postnatal changes in retinal ganglion cell and optic axon populations in the pigmented rat. $J$ Comp Neuro/219: 356-68.

PRADA, C., PUGA, J., PEREZ-MENDEZ, L., LOPEZ, R. and RAMIREZ, G. (1991). Spatial and temporal patterns of neurogenesis in the chick retina. EurJNeurosCi 3: 559-569.

RODRIGUEZ-TEBAR, A., JEFFREY, P.L., THOENEN, H. and BARDE, Y.A. (1989). The survival of chick retinal ganglion cells in response to brain-derived neurotrophic factor depends on their embryonic age. Dev Biol 136: 296-303.

SALVESEN, G.S. and DUCKETT, C.S. (2002). lap proteins: Blocking the road to death's door. Nat Rev Mol Cell Bio/3: 401-10.

SANVICENS, N., GOMEZ-VICENTE, V., MASIP, I., MESSEGUER, A. and COTTER, T.G. (2004). Oxidative stress-induced apoptosis in retinal photoreceptor cells is mediated by calpains and caspases and blocked by the oxygen radical scavenger cr-6. J Biol Chem 279: 39268-78.

SERNAGOR, E., EGLEN, S.J. and WONG, R.O. (2001). Development of retinal ganglion cell structure and function. Prog Retin Eye Res 20: 139-74.

SLEE, E. A., HARTE, M. T., KLUCK, R. M., WOLF, B. B., CASIANO, C. A., NEWMEVER, D. D., WANG, H. G., REED, J. C., NICHOLSON, D. W., ALNEMRI, E. S., GREEN, D. R., MARTIN, S. J. (1999). Ordering the cytochrome c-initiated caspase cascade: hierarchical activation of caspases-2, $-3,-6,-7,-8$ and -10 in a caspase-9-dependent manner. J Cel/ Bio/144: 281-92.

SPALDING, K.L., DHARMARAJAN, A.M. and HARVEY, A.R. (2005). Caspaseindependent retinal ganglion cell death after target ablation in the neonatal rat. Eur J Neurosci21: 33-45.

SUZUKI, Y., IMAI, Y., NAKAYAMA, H., TAKAHASHI, K., TAKIO, K. and TAKAHASHI,
R. (2001). A serine protease, htra2, is released from the mitochondria and interacts with xiap, inducing cell death. Mol Cel/8: 613-21.

TEZEL, G. and YANG, X. (2004). Caspase-independent component of retinal ganglion cell death, in vitro. Invest Ophthalmol Vis Sci 45: 4049-59.

VANDER HEIDEN, M.G., CHANDEL, N.S., WILLIAMSON, E.K., SCHUMACKER, P.T. and THOMPSON, C.B. (1997). Bcl-xl regulates the membrane potential and volume homeostasis of mitochondria. Cel/91: 627-37.

VECINO, E., HERNANDEZ, M. and GARCIA, M. (2004). Cell death in the developing vertebrate retina. Int J Dev Bio/48: 965-74.

VEKRELLIS, K., MCCARTHY, M.J., WATSON, A., WHITFIELD, J., RUBIN, L.L. and HAM, J. (1997). Bax promotes neuronal cell death and is downregulated during the development of the nervous system. Development 124: 1239-49.

VERHAGEN, A.M., EKERT, P.G., PAKUSCH, M., SILKE, J., CONNOLLY, L.M., REID, G.E., MORITZ, R.L., SIMPSON, R.J. and VAUX, D.L. (2000). Identification of diablo, a mammalian protein that promotes apoptosis by binding to and antagonizing iap proteins. Ce//102: 43-53.

VON BARTHELD, C.S., BYERS, M.R., WILLIAMS, R. and BOTHWELL, M. (1996). Anterograde transport of neurotrophins and axodendritic transfer in the developing visual system. Nature 379: 830-3.

WANG, S.W., KIM B.S., DING, K., WANG, H., SUN, D., JOHNSON, R.L., KLEIN, W.H., GAN, L. (2001) Requirement for Math 5 in the development of retinal ganglion cells. Genes. Dev. 15: 24 - 29

WANG, X., BUTOWT, R., VASKO, M.R. and VON BARTHELD, C.S. (2002). Mechanisms of the release of anterogradely transported neurotrophin-3 from axon terminals. J Neurosci22: 931-45.

WEI, M.C., ZONG, W.X., CHENG, E.H., LINDSTEN, T., PANOUTSAKOPOULOU, V., ROSS, A.J., ROTH, K.A., MACGREGOR, G.R., THOMPSON, C.B. and KORSMEYER, S.J. (2001). Proapoptotic bax and bak: A requisite gateway to mitochondrial dysfunction and death. Science 292: 727-30.

WHITE, F.A., KELLER-PECK, C.R., KNUDSON, C.M., KORSMEYER, S.J. and SNIDER, W.D. (1998). Widespread elimination of naturally occurring neuronal death in bax-deficient mice. J Neurosci 18: 1428-39.

WILLIAMS, R.W., STROM, R.C., RICE, D.S. and GOLDOWITZ, D. (1996). Genetic and environmental control of variation in retinal ganglion cell number in mice. $J$ Neurosci 16: 7193-205.

WILLIS, S.N. and ADAMS, J.M. (2005). Life in the balance: How bh3-only proteins induce apoptosis. Curr Opin Cell Bio/17: 617-25.

YAKOVLEV, A.G., OTA, K., WANG, G., MOVSESYAN, V., BAO, W.L., YOSHIHARA, K. and FADEN, A.I. (2001). Differential expression of apoptotic proteaseactivating factor- 1 and caspase- 3 genes and susceptibility to apoptosis during brain development and after traumatic brain injury. J Neurosci21: 7439-46.

YANG, J., LIU, X., BHALLA, K., KIM, C.N., IBRADO, A.M., CAI, J., PENG, T.I., JONES, D.P. and WANG, X. (1997). Prevention of apoptosis by bcl-2: Release of cytochrome c from mitochondria blocked. Science 275: 1129-32.

YOUNG, R.W. (1984). Cell death during differentiation of the retina in the mouse. $J$ Comp Neuro/229: 362-373.

YOUNG, R.W. (1985a). Cell differentiation in the retina of the mouse. Anat Rec212: 199-205.

YOUNG, R.W. (1985b). Cell proliferation during postnatal development of the retina in the mouse. Brain Res 353: 229-39.

YUAN, J. and YANKNER, B.A. (2000). Apoptosis in the nervous system. Nature 407: 802-9.

ZEISS, C.J., NEAL, J. and JOHNSON, E.A. (2004). Caspase-3 in postnatal retinal development and degeneration. Invest Ophthalmol Vis Sci45: 964-70.

Received: March 2006 Reviewed by Referees: April 2006 Modified by Authors and Accepted for Publication: July 2006 Published Online: September 2006 